\title{
RATIONALIZING THE PERMISSIBILITY OF MOSQUE DECORATION
}

\section{Received March 15th 2016 | Accepted April 18th 2016 | Available online June 30th 2016}

DOI http://dx. doi.org/10.18860/jia.v4i1.3391

Spahic Omer

Intenational Islamic University

Malaysia

spahico@yahoo.com

\begin{abstract}
This paper discusses the subject of mosque decoration and some of the criteria which determine its permissibility or otherwise. Some aspects of the matter are somewhat sensitive and double-edged. Thus, the paper presents an objective, balanced and scientific account of the theme, steering clear of the sentimental aspects of the evidences often put forth by both the proponents and opponents of mosque decoration. The main thrusts of the paper are the issues pertaining to the legitimacy of decoration in general, the subject of the function of mosques vis-à-vis their decoration, as well as the broad guidelines that regulate mosque decoration emphasizing the decoration of the mihrab (praying niche) area and the qiblah wall. The paper concludes that in principle mosque decoration is permissible so long as it conforms to the requirements of the Islamic spirituality and the quintessence of genuine Islamic art and architecture.
\end{abstract}

KEYWORDS :

Mosque Decoration; Islam; Mihrab; Qiblah Wall

\section{INTRODUCTION}

Islamic art and architecture divide opinion both among Muslims and non-Muslims. Mosque decoration is a subject that stands at the forefront of such debates. So serious is the matter that discussions do not revolve only around how mosque decoration is to be perceived and executed, but also whether such an undertaking is permissible or not in the first place [1], [2], [3], [4]. This paper attempts to demonstrate that, as an integral part of the orbs of Islamic art and architecture which denote a microcosm of Islamic culture and civilization, the theme of mosque decoration cannot be extricated from the religious and socio-economic factors that formulated and gave rise to it, and be treated in isolation. Unraveling the misapprehensions that surround the theme at hand depends considerably on how successfully mosque decoration is related to those religious and socioeconomic contexts.

\section{THE LEGITIMACY OF DECORATION}

The Prophet Muhammad (pbuh) not only totally ignored the subject of decoration and ornamentation while building and overseeing others who were building during his lifetime, but he also, at first glance, denounced the matter in several of his hadiths (traditions). In one of them, he is reported to have said that whenever a people's performance ('amal) weakens, they then start decorating their mosques [5].

In another tradition, the Prophet (pbuh) said that one of the signs of the imminence of the Day of Judgment is when people start boasting against one another with regard to building pursuits[6], including planning, construction, decoration and everything else related to built environment. This applies to the mosque institution as well [7].

The Prophet (pbuh) also disclosed that he was not directed (ma umirtu) to erect (tashyid) monumental mosques. The narrator of the last hadith, 'Abdullah b. 'Abbas, commented: "You shall certainly end up adorning your mosques as both the Jews and Christians did"[8]. Surely, "Abdullah b. "Abbas did not say this of his own accord; rather, he just paraphrased a hadith in which the Prophet (pbuh) is reported to have uttered the same.

Furthermore, the Prophet (pbuh) commanded that every cloth or curtain decorated with figured designs be removed from the places of prayer lest they disturb people's prayers. He himself set a standard by doing so on a few occasions [9], [10]. According to yet another hadith, every house ought to be free of those articles which may get in the way of the absorption of those who perform their prayers there [11].

On one occasion the Prophet (pbuh) refused to enter a house to which he had been invited because in the house there was a figured curtain. When asked for the reason of his refusal, the Prophet (pbuh) replied: "It is not fitting for me or for any prophet to enter a house which is decorated"[12]. In fact, there are so many traditions of the Prophet (pbuh) to the effect that angels do not enter a house in which there is a picture or portraits [13].

The Prophet (pbuh) is also reported to have said, on seeing an imposing dome erected over a house in Madinah, that every building activity is harmful to its executor unless it is carried out due to a 
necessity [14].

This uncompromising attitude of Islam towards wasted and unjustifiable building and decoration practices has been encapsulated, so to speak, in the following words of the Prophet (pbuh): "We have not been commanded to dress (embellish) stones and clay (bricks)"'[15]. This account of the Prophet (pbuh) was reported by his wife A'ishah. She said that the Prophet (pbuh) once set out for an expedition. She took a carpet and screened the door with it. When the Prophet (pbuh) came back, he saw that carpet and A'ishah perceived signs of disapproval on his face. He pulled it until it was torn, or it was cut (into pieces), and he said: "God has not commanded us to clothe stones and clay." A'ishah said that they cut the curtain and prepared two pillows out of it by stuffing them with the fiber of date-palms and the Prophet (pbuh) did not find fault with it.

Moreover, the Holy Qur'an mentions house decoration and ornamentation (zukhruf) twice: in the chapter al-Isra', verse 94, wherein the extent of the Makkan polytheists' addiction to materialism and selfish fancies and aims has been exposed; and in the chapter al-Zukhruf, verse 35, wherein the subject of excessive house embellishment, the keyword to the chapter, has been presented as the false glitter and adornments, not only in houses (built environment) but also in all other things related to this world, to which so little value is attached in the spiritual world. The same more often hinders than helps [16].

Nevertheless, the hadiths (traditions) and Qur'anic verses referred to in no way imply that decoration in the art of building was meant to be prohibited altogether. If such were the case, both the Holy Qur'an and the Prophet's Sunnah would have been more specific and explicit because every prohibition (haram) by both of them, or by any of them independently, is precise and lucid containing no ambiguity [17]. Allah says: " ... when $\mathrm{He}$ hath explained to you in detail what is forbidden to you... [18].

Furthermore, to assert that moderately beautifying and decorating buildings, including mosques, have been prohibited would be in many ways in conflict with the gripping reality and the practices of the Muslims throughout history, whereas it is commonly accepted that the Muslim community will, under no circumstances, agree on an error [19]. One of the Prophet's companions, 'Abdullah b. Mas'ud, is reported to have said about this: "What the Muslims end up regarding as a propriety, God too will regard it that way; likewise, what they end up regarding as a sin, God too will regard it as such"[20].

Indeed, the Prophet (pbuh) harshly criticized inappropriate decoration, but did not denounce the idea of decoration and beautification as such. It could be said, therefore, that the matter rests within the sphere of permissibility (ibahah) so long as something does not come about and cause it to infringe some of the divinely prescribed standards, and hence render it abhorrent and even forbidden. This conclusion can be drawn from the way Islam generally treats the subjects of entertainment, beautification and enjoying the legitimate delights of this world. These are all in principle permitted in Islam. However, should they be unduly practiced or utilized, thereby breeding falseness and wrongdoing, they will instantaneously become abhorred and so disapproved of. Permissible activities such as eating, drinking, sleeping, relaxing the body and mind, etc., all can turn out to be bad if they become saturated with transgression and sin.

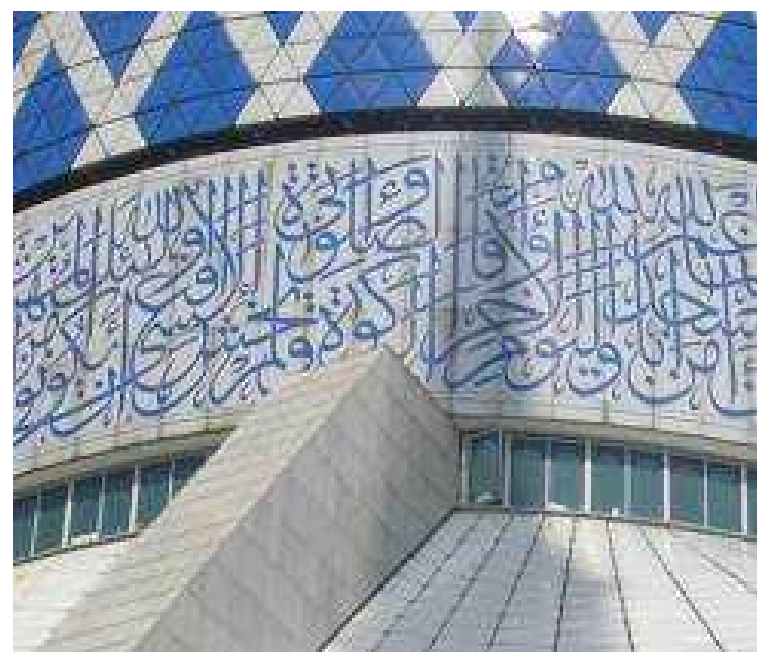

Figure 1. Calligraphy adorning the base of the dome of the Shah Alam Mosque in Shah Alam, Malaysia.

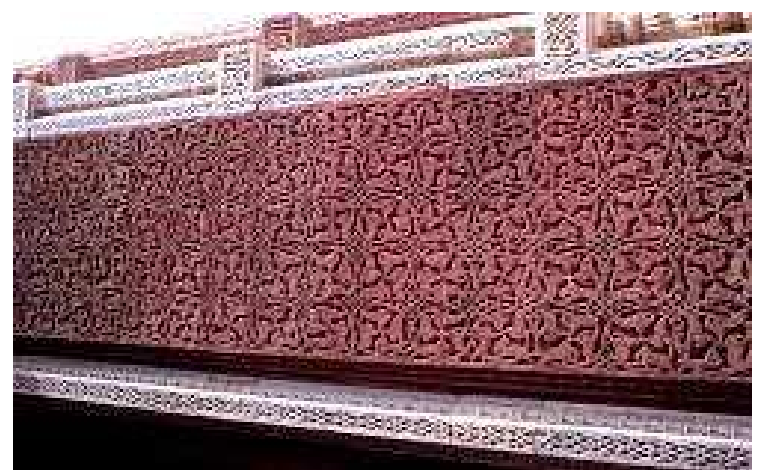

Figure 2. Intricate floral arabesque in the Quwwat ul-Islam Mosque in New Delhi, India.

\section{THE FUNCTION OF MOSQUES VIS-À-VIS THEIR DECORATION}

Surely, the subject of decorating mosques -among other aspects of Islamic built environment -- is the most talked-about and at times a controversial one. Hence, it deserves some special attention.

The Prophet's traditions on mosque decoration that we have highlighted earlier seem at first glance to be against the matter in question. However, such is not the case, and the whole thing must be studied carefully taking into consideration a number of religious and socio-economic factors.

If the Prophet (pbuh) intended to prohibit totally 
the acts of beautifying and decorating mosques, either he or the Qur'an would have done it in ways that neither contained ambiguity nor left room for any doubt. It will never be the case that the entire Muslim community will be in agreement on a matter that the Islamic message does not authorize. Nor will it ever be the case that all Muslims will become inclined to forsake a matter that Islam has imposed on them. Needless to note, though, this is just one of the many realities that typify the last message to mankind and the community of the seal of prophets. Prior to the sending of the last Messenger to men, i.e., Muhammad (pbuh), the same principle hardly existed, or perhaps never existed at all, with other nations and communities. It is a compelling fact that beautifying and decorating mosques, with sharply varied degrees and styles yet with the identical message and philosophy, is evident virtually everywhere from the moment the idea of beautifying mosques had been instituted till today. It follows that such a strong phenomenon as mosque decoration in the Muslim world, which is proper and aids spiritual interests, is redolent of its intrinsic permissibility.

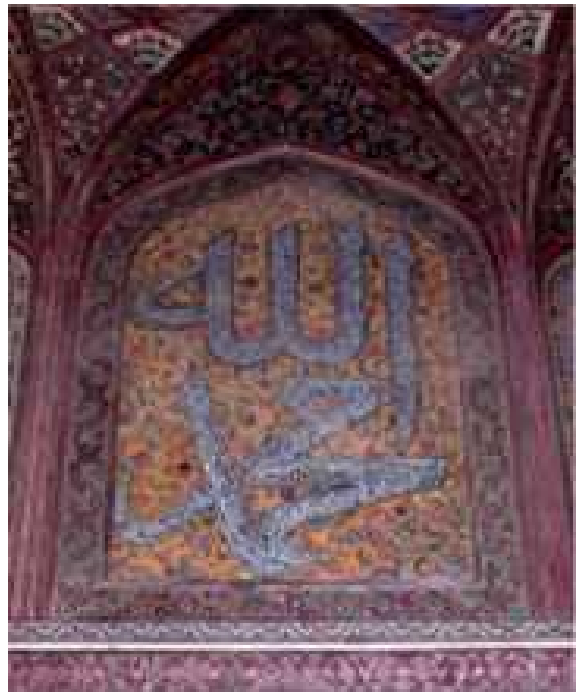

Figure 3. A variety of decorative styles are to be often found interwoven. Detail of decoration in the Wazir Khan's Mosque in Lahore, Pakistan.

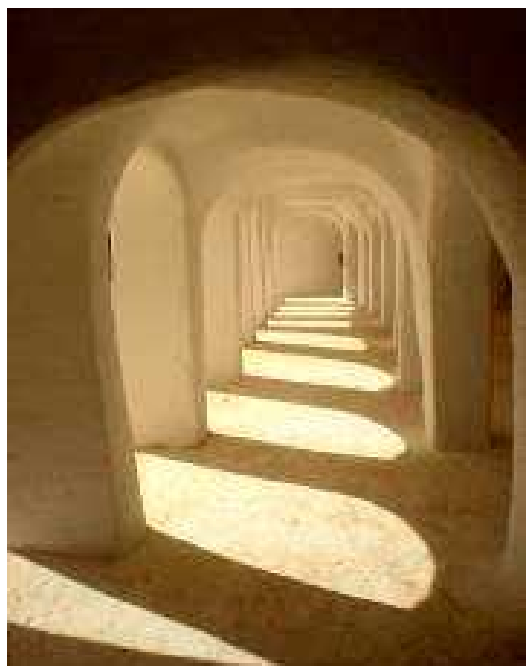

Figure 4. The plain interior of a mosque in Ghardaia, Algeria.

Certainly, the Prophet's traditions (hadiths) in question have been uttered in the context of the status of the mosque institution in society and what kind of relationship between it and men ought to exist. The mosque is the nucleus of the believers' existence. Throughout the history of mankind it epitomized the never-ending struggle for supremacy between good and evil [21]. For the mosque to play the role of a center for the development of communities is a paramount priority which must remain unchanged, despite the developments that societies constantly go through. Other valid societal roles could be attached to the authority of the mosque institution, but they all must remain second to the topmost role for which the mosque had been instituted, further promoting and enhancing it.

The Prophet Muhammad (pbuh) apparently wished to warn his followers as to the consequences that will inevitably occur if they set out to neglect the real functions of mosques and become more interested in their physical appearance instead. Should that happen, the followers of Islam must not live under the illusion that they by some "innovative" means defend and advance God's religion. On the contrary, they must be aware that the phenomenon of excessive and meaningless mosque beautification and decoration is but a disease endemic only in places where a people's faith has drastically declined and total submission to the Almighty has no longer remained a priority. That means, furthermore, that the objectives of the Islamic Shari'ah (Law) have been forsaken and other alternatives have been pursued instead. As a remedy to the whole thing, which constitutes an effect, the Prophet (pbuh) advised that working on annihilating the causes be the sought course of action, for so long as the causes of the malady are extant and nourished, the effects will keep cropping up and thriving.

How serious the problem at hand can become illustrates the fact that some people, if left unimpeded and their erroneous perceptions about mosques not corrected on time, would reach the point where the actions of theirs will resemble those of the Jews and Christians, who have drawn on themselves the wrath of God with myriad acts of dishonesty, distortions and deception. About the latter the Prophet (pbuh) once said, after he had been told of the beauty of a church in Abyssinia (Ethiopia) and how wonderful its paintings are: "Those people, when a pious man among them dies, on his grave they construct a mosque (a place of worship) which they paint with those pictures. They are the worse creation before Allah"[22]. Hence, the Prophet (pbuh) sternly warned the Muslims of imitating the Jews and Christians in matters pertaining to decorating the places of worship.

Relinquishing and burying the true position and role of mosques also means relinquishing and burying the tasks that man has been assigned to carry out on earth. In that case, some of the first definitive steps towards abandoning the Islamic paradigm and welcoming those which are alien to the Islamic world- 
view instead, would be introduced. The verity that Islam as a comprehensive way of life was revealed to raze people's erring living patterns, furnishing them with those based upon tawhid (God's Oneness) as an alternative, will therewith become no longer relevant and adhered to. In consequence, wandering divorced from divine guidance, men will become increasingly corrupt, and so will their relations with the Creator, people and nature. Under the circumstances, the whole situation will have a potential to evolve so far as to become an integral part of the boundless chaos that will herald the imminence of the Day of Judgment, which the Prophet (pbuh) has alerted people to in one of the earlier cited traditions. Many persons for aiding evil and obstructing good will at this particular juncture grow to be inclined to misuse and manipulate even the institution of the mosque.

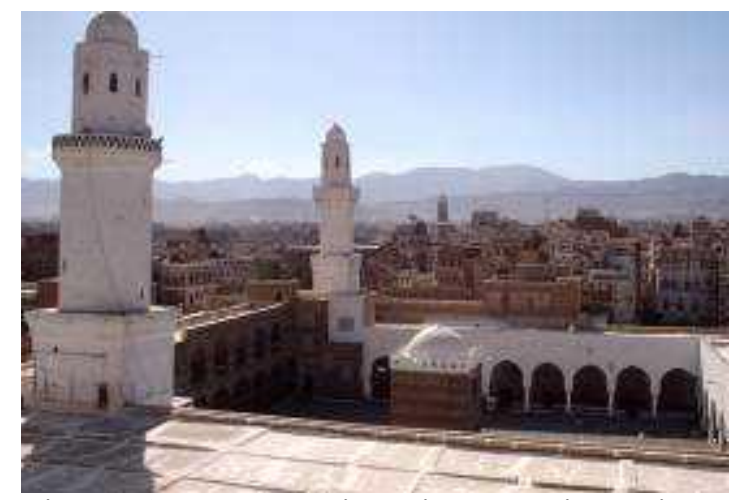

Figure 5. The Great Mosque in Sana'a, Yemen. It is an ancient mosque dating to the $1^{\text {st }} \mathrm{AH} / 7^{\text {th }} \mathrm{CE}$ century. Some legend even traces the Mosque's history to the era of the Prophet Muhammad (pbuh), although there is no evidence to substantiate such a claim.

Thus, one of the Prophet's traditions suggest that of the signs of the Day of Judgment's nearness is when people start decorating their mosques without using them for the purposes for which they had been ordained by heavenly decree. It is not by chance that this message of the Prophet (pbuh) came after his words on neglecting the injunction of enjoining good and forbidding evil (al-amr bi al-ma'ruf wa al-nahy 'an al-munkar). It looks as though the Prophet (pbuh) thus wanted to communicate that the relationship between the two phenomena is a causal one, the former being the cause and the latter the effect, and so the people must be watchful.

Ali b. Abi Talib is also reported to have said that of the signs of the Day of Judgment's nearness is: "decorating mosques, raising minarets and skipping congregational prayers"[23]. Here too, like what has been mentioned earlier, by decorating mosques it is meant that people show more interest to the outer appearance of mosques while neglecting its spiritual dimension. For this reason, certainly, did Ali b. Abi Talib cite the decoration of mosques and lofty minarets alongside congregational prayers. Without the latter, which exemplifies the core of the projected position and function of mosques, the former not only becomes a worthless exercise, but also generates God's displeasure and more than a few grave sins.

Without a doubt, Islam prohibits extravagant mosque beautification and decoration, more so when the same is done for advancing certain people's personal interests or for any other reason that may cause even the slightest harm to the wellbeing of Muslims and their community [24]. This verdict can easily be deduced from the strict and unequivocal Islamic prohibition of wastefulness, injustice, causing harm, wealth misappropriation, haughtiness, ostentation, and so on. Not only on private but also public property does this ruling apply, as both are from God who bestows His gifts of sustenance more freely on some than on others in order that He may test them as to which of them are best in conduct [25].

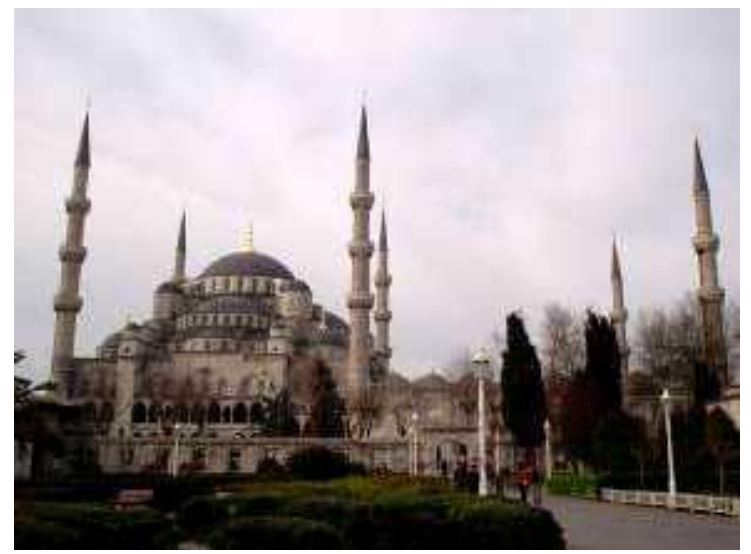

Figure 6. The Blue Mosque (Sultan Ahmed Mosque) in Istanbul, Turkey. It is called "Blue" for the blue tiles that adorn the walls of the Mosque's interior.

\section{MOSQUE AND COMMUNITY BUILDING}

On the other hand, raising mosques as a response to the demands of the intensive personality and society building processes brought about by the ceaseless Islamization efforts on the hands of individuals and groups is very laudable since whosoever builds for the sake of God and His religion a mosque -- irrespective of its size -- God will build for him a house in Paradise (Jannah) [26], [27]. But constructing grand mosques for the sake of mere construction or for any other reason whereby the splendid objectives of Shari'ah (Islamic Law) are disregarded, one way or another, is an abominable and thus seriously censured exercise. This is the message of the Prophet's words cited earlier: "I am not directed to erect monumental mosques."

On the same note, the Prophet (pbuh) once declared that the purpose of building mosques is for people to remember God, perform prayers and recite the Holy Qur'an [28]. That is, to worship God alone. All the facilities and services that are bound to serve and stimulate the mentioned mission of the mosque -- it stands to reason -- are welcome in mosques. Conversely, all the elements that are against the mission of mosques, or they tend to get in the way of 
its fulfillment, are forbidden [29]. Based on this premise, inappropriate and disconcerting decoration schemes must be disallowed altogether. However, if certain suitable decoration schemes do really motivate and support different worship ceremonies held in mosques, one can make a case as to why they should not then be not only permitted, but also promoted at various levels.

The forms, design, plan and function of mosques ought to be inspired solely by the Islamic faith. All aspects of mosques are to be permeated with the Islamic spirit and stand as the embodiment of Islamic principles and values. In spaces that are contained in the forms and plans of mosques, the worship activities of people must be facilitated and their desire to perform them stirred up. The generated atmospheres of mosques should be conducive to enhancing people's spirituality, and to enriching the spirit of unity, equality and brotherhood among all Muslims. Size, therefore, along with the overall physical appearance of mosques, is inferior and matters only when it comes into complete conformity with the aforementioned criterion. That is why when dwelling on several occasions on the issue of mosques and their creation, the Prophet (pbuh) clearly emphasized the significance of the function and utility of mosques, ahead of anything else, saying, for example: "He who builds a mosque where people will pray..."[30] or "He who builds a mosque where God will be remembered..." [31]. In both expressions, the act of building a mosque is conditioned and legitimized by the function of a future structure that will adorn it. Otherwise, the legitimacy of the act of building and of buildings themselves would be dubious. Their presence will be rather a liability to the community. Allah also says about this: "(Lit is such a Light) in houses, which Allah hath permitted to be raised to honor; for the celebration, in them, of His name: in them is $\mathrm{He}$ glorified in the mornings and the evenings (again and again) [32].

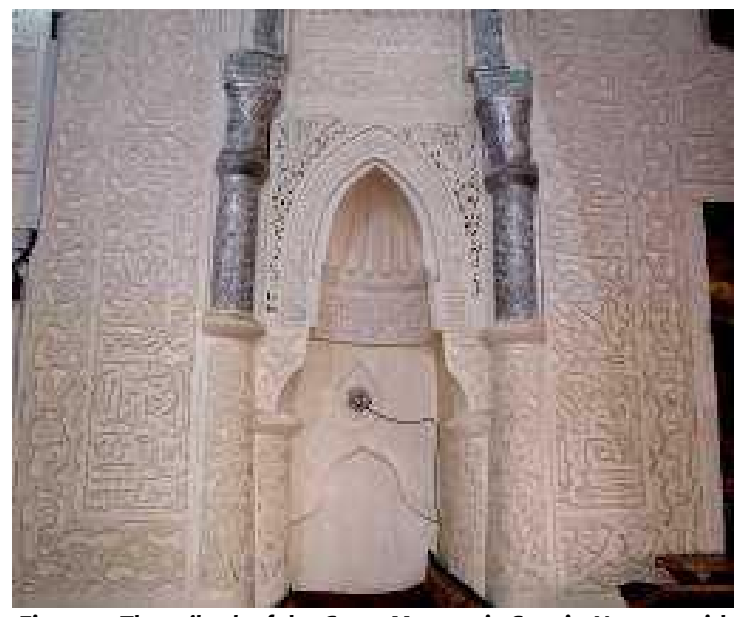

Figure 7. The mihrab of the Great Mosque in Sana'a, Yemen, with some excessive decoration around it.

Although the Prophet (pbuh) did not prohibit meaningful and moderate mosque beautification and decoration altogether, yet he did not explicitly permit it either. Whether decorating mosques is permitted or prohibited is thus conditioned chiefly by people's intentions and goals, as well as by the roles both mosques and their deco rative styles and elements play. Nonetheless, in some of his utterances and actions, the Prophet (pbuh) did, to some extent, indirectly set the stage for the genesis of the matter as soon as the conditions for it became favorable and compelling, on the exclusive condition that the divinely prescribed standards were strictly adhered to. If one looks at the Prophet's mosque in Madinah, unadorned and simple in the extreme, as it initially was, one could easily notice that it in a short time began to gradually, albeit insignificantly, metamorphose in terms of both its form and function. A number of significant changes took place even during the Prophet's time.

The Prophet's mosque was initially built just as an enclosure without even a roof, with bare ground, and with hardly any facility inside. But changes, some quite significant, soon started to befall it. Some of the most notable changes that happened to the Prophet's mosque in terms of both form and function during the Prophet's era are: roofing the mosque; covering the mosque's ground with pebbles; introducing some mats made of palm branches and big enough to accommodate the face and hands to be placed on during prostration; the introduction of the minbar (pulpit); perfuming the mosque especially for Friday Prayer (Jumu'ah); illuminating the mosque by burning up fronds and later lighting lamps; the introduction of the Prophet's dakkah or dukkan (seat, bench). Needless to say, furthermore, that the Prophet (pbuh) paid so much attention to the cleanliness and tidiness of his mosque that a woman was assigned to perform the tasks of maintaining the mosque clean and tidy. The Prophet (pbuh) has uttered so many traditions in connection with the cleanliness and tidiness of mosques [19].

In addition to serving as a place for congregational prayers, as well as for other collective worship ('ibadah) acts, the Prophet's mosque likewise furnished the Muslims with other crucial social amenities: it was the seat of the Prophet's government, a learning center, a kind of hospital, a rehabilitation center, a welfare center, and the place for some legitimate recreational activities. So eventful and bustling with life was the Prophet's mosque that after several years of existence it started to show signs that it could no longer comfortably accommodate the ever-growing number of worshippers, especially on Fridays. It therefore had to be enlarged, which the Prophet (pbuh) did following the conquest of Khaybar in the $7^{\text {th }}$ year after the Hijrah. Shortly before his death, the Prophet (pbuh) is said to have implied that his mosque should be expanded for the second time[33].

Since it was a religious and community development center with activities of various types conducted under its roof, the early changes rendered to the mosque proper were but in response to the 
increasingly complex needs and requirements of the fast growing Muslim community. After the Prophet's death, the form and function of the mosque institution continued to react to the changes and developments that never ceased to feature in Islamic civilization, as a result of the impact of the perennial time and space factors which Islam duly recognized. Having always played the role of the community center, the evolution of the mosque institution personified the evolution of the Islamic community and its eclectic cultures and civilization. Eventually, since the idea of moderately and meaningfully decorating and beautifying objects and buildings has a role to play in Islam, one gets a feeling that the evolution of the Prophet's mosque, and the mosque institution in Islam taken as a whole, was inescapably moving toward a point where a stand will have to be made vis-à-vis the rapid progression of Islamic art and architecture following the rapid expansion of the Islamic community and civilization, coupled with the increased interaction of the Muslims with other cultures and civilizations.

Obviously, unlike other segments of the Islamic built environment where the subject of decoration was seen nigh on as a normal occurrence, decoration in mosques was making slow progress. When this changed, however, it was not really welcomed with much enthusiasm from many quarters of the society, especially certain scholars and pious individuals. The whole thing was seen by many as an acceptable phenomenon only due to the strain of the prevailing socio-political circumstances. It is said, for an instance, that when Caliph al-Walid b. Abd al-Malik embarked on decorating mosques in ways and intensity hitherto unknown to the Muslims, there were some people, including scholars, who showed their reservations about some aspects of the matter, but they too at the end either gave in or somewhat accustomed themselves to the new trend, tolerating its presence and refusing to openly voice their objections for fear that discord might ensue among the Muslims [34]. They, too, at the end felt that their objections to a matter which the Prophet (pbuh) did not explicitly prohibit, but only raised some reservations about and warned against some aspects related to it, did not merit a confusion or a conflict among the Muslims, which is unmistakably one of the most loathed things to God and His Messenger.

\section{JURISTS' VIEWS ON MOSQUE DECORATION}

Surely, decorating mosques is a sensitive and double-edged thing which must be handled cautiously and wisely. If mismanaged and the goals of beautification in Islam ignored or not realized, the same can easily be turned into an objectionable activity (makruh) and even in an outright transgression (haram). It was because of this, as well as because of the fact that when it comes to decoration and beautification some people tend to stop at nothing, that some doctors of Shari'ah (Islamic
Law) were rather cautious about the issue of decorating the places of worship. The jurists from the Maliki and Hanbali schools maintained that avoiding decorating mosques after all remains a priority. Should absolute avoidance be impossible, it then needs to be reduced to a minimum. The same schools of thought asserted, furthermore, that writing anything on the entire qiblah (prayer direction) wall, regardless of purpose, should be disallowed, whereas the same to some extent can be tolerated on the rest of the walls. To the Maliki and Hanbali schools of law, mosque decoration is an abominable religious innovation (bid'ah) which neither the Prophet (pbuh) nor the first and exemplary Muslim generation (sahabah) resorted to. Many companions of the Prophet (pbuh), such as Abu Hurayrah, Abu al-Darda', Abu Dharr and Abu Sa'id, were of the opinion that decorating mosques meant incurring self- ruin [35].

Abu Hanifah, the founder of the Hanafi school of law, sanctioned the matter of mosque decoration, provided the money used for it is acquired through legitimate means (halal). Some from the Hanafi school even see the matter as a highly praiseworthy act, as it signifies the exaltation of the mosque institution and the ideals that underpin its existence. Since people feel inclined to decorate their houses, shops, schools, etc., their mosques should be moderately decorated as well. If not, some unscrupulous people, or those with weak and vulnerable faith, might accord mosques less respect and appreciation. Accordingly, mosque decoration is regarded as an affirmative and constructive innovation [36].

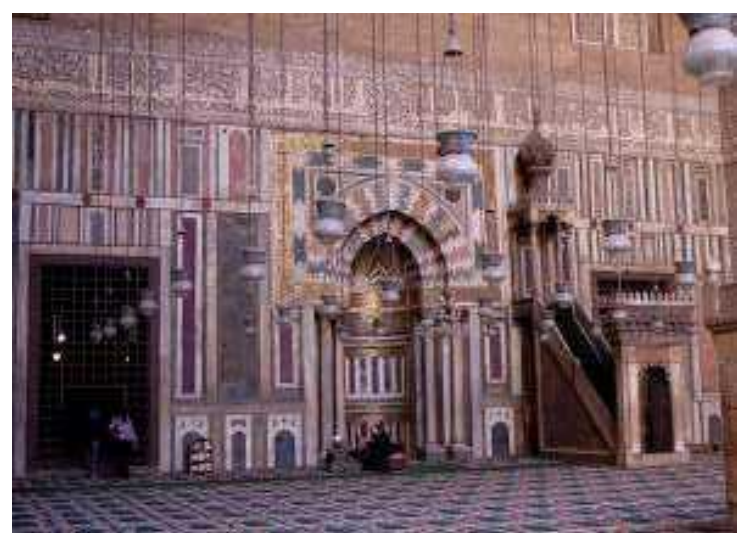

Figure 8. The qiblah side of the madrasah (school)-cum-Mosque of Sultan al-Hassan in Cairo, Egypt.

For most scholars, however, though moderate decoration is lawful, yet the mihrab (imam's praying niche) should be left undecorated lest the worshippers should be disturbed by its decorative patterns, as the mihrab area is the central point of congregational prayers. Abu Hanifah initially subscribed to this view too, but later made some concessions and permitted it; so did Abu Talib alMakki, a famed scholar and sage of the fourth Hijrah century [35], [3].

Nonetheless, most scholars are unanimous that gold and silver should not be used for mosque decoration, because mosques are public places and 
so, the poor and less fortunate might feel bad about it. In addition, such is a sheer act of extravagance and wasting irrespective of how affluent people might be. Money used for decoration, furthermore, apart from the fact that it must be lawful (halal), it likewise cannot be from endowment funds (waqf), as decoration is not intrinsically part of building; it is its superfluous supplement [3], [37].

The case of the caliph Umar b. Abd al-Aziz with the Great Umayyad Mosque in Damascus somewhat epitomizes the whole mosque decoration concern. It has been reported that Umar b. Abd al-Aziz, who was the caliph al-Walid's governor in Madinah during the latter's reign, upon becoming the caliph started harboring a few misgivings about the ways the Great Umayyad Mosque had been built, especially about its decoration and ornamentation which he thought were rather excessive. Umar, himself an extremely devout and austere person, at one point went so far as to contemplate to replace the Mosque's decoration with some cheaper and less likable materials like mud and gypsum, as well as to sell some of the Mosque's expensive ornaments and then to return the collected income to the public treasury. Umar b. Abd al-Aziz saw decoration on the qiblah side facing the Ka'bah in Makkah as most problematic as it had a potential to disturb people in their prayers not allowing them to fulfill a very important requirement in prayers, i.e., spiritual concentration [38].

However, the people succeeded in convincing Umar b. Abd al-Aziz that in the ways the Mosque had been conceived, planned and built, good intentions and goals prevailed. No outright transgression was ever meant. What appeared to be somewhat faulty, however, was never intended to be as such. It was a result of people's ijtihad, i.e., a process of forming an opinion or judgment within the framework of an existing evidence. The positive aspects in a few slightly problematic elements of the Mosque still outweighed the questionable ones. Thus, there was no need for new sensitive initiatives which, in the final analysis, could bring more damage than benefit to people. For example, when Umar b. Abd al-Aziz proposed to remove the golden decoration from the Mosque's qiblah side and whitewash the wall with gypsum instead, he was told that the new job would incur new expenses, which they all wanted to avoid. When he proposed to coat the Mosque with earthenware and thus conceal its splendor, he was told that that would be similar to how the Ka'bah looked like, which would have entailed new potentially hazardous issues, which they all desired to avoid. Umar b. Abd al-Aziz was also told that whenever the money of Muslims is collected and used for a purpose, there must be some benefit in it.

At the end, Umar gave up his thoughts. It goes without saying that if there was an outright offense committed in the process of building the Great Umayyad Mosque, Umar b. Abd al-Aziz, certainly, would not have budged easily as he did, and would have carried through his "purification" plans at all costs. That would have been incumbent upon him in his capacity as the commander of believers, and nobody could be better aware of that than Umar b. Abd al-Aziz. Umar b. Abd al-Aziz was pacified most by the fact that the Great Umayyad Mosque in its grandeur served to believers as a source of pride, confidence and zeal, but to non-believers as a source of unease, inferiority complex and defeat [38].

\section{BROAD GUIDELINES THAT REGULATE MOSQUE DECORATION}

Summing up the section on the significance of the relationship between the functions and decoration of mosques, the following guidelines could be deduced from the views of Muslim jurists with regard to the legitimacy of mosque decoration:

1. Mosque decoration is not prohibited (haram). The most that has been said about mosque decoration is that it is an abhorrent act (makruh).

2. Decoration must not interfere with people's concentration in prayers and in other worship activities. It should be borne in mind, however, that praying while facing some decorative patterns does not invalidate one's prayer. When the Prophet (pbuh) performed a prayer facing a cloth or a curtain decorated with figured designs -- as said earlier -- he neither stopped his prayer so that he could pray elsewhere nor did he repeat the prayer afterward. It should be remembered, furthermore, that there are many categories of decoration strategies. They are not all the same. As such, they all must be given their corresponding attention and treatment. Some strategies are more detrimental to one's concentration in prayers and others less. Judging by the Prophet's reaction, the decorative patterns he faced in a prayer must have ranked high in terms of detriment to properly experiencing prayers. At any rate, it would be grossly unfair to say on the strength of the above-mentioned tradition and other similar ones in content that the Prophet (pbuh) was against decoration per se. Rather, he was only against such artistic expressions as could hinder one's attempts to focus in his prayers. As a matter of fact, and by analogy, the Prophet (pbuh) was against not only decoration but also all the worldly pursuits that could impede people's progression toward the spiritual fulfillment on earth.

3. Decoration must not be extravagant so that wastefulness is committed.

4. Mosques are not to be decorated at the expense of providing some other societal facilities and services.

5. Mosque decoration is never to supersede in importance the primary functions of mosques.

6. Appropriate mosque decoration signifies that the mosque institution, together with the ideals that called for its existence, is honored. It is improper that while people enjoy relatively high life standards and live in comfortable and embellished, many even in outsized and exalted, 
dwellings, mosques are built austere and unadorned. Many feared that if such becomes a scenario, the persons of fluctuating faith might despise mosques and all the matters related thereto. This, for the most part, was behind the people's approval for the decoration of mosques. As it was behind the change of mind in those who in the beginning appeared to be against mosque decoration, seeing it as an unwelcome innovation in religion, but later gradually changed their standpoint.

This can be further elucidated by the following. Islam insists that its followers come to general gatherings, including collective prayers, nicely dressed and well-groomed [39]. The Muslims are actually urged to do so whenever they can so that the effects of Allah's favors upon them could be always seen, as expounded by the Prophet (pbuh) on more than a few occasions [40], [41]. If this is the case with the people who make up the best community evolved for mankind (the best Ummah), the same is then true, perhaps to a greater extent, about the institutions -- the chief of which is the Mosque institution -- without which no realization of such an illustrious position of the Muslims on earth would otherwise ever be possible. Mosque decoration is seen as an avenue for making the effects of Allah's favors upon Muslims to be seen, thus thanking Him for everything. Allah the Most High says: "Say who hath forbidden the beautiful (gifts) of Allah which $\mathrm{He}$ hath produced for His servants, and the things, clean and pure, (which He hath provided) for sustenance? Say: They are, in the life of this world, for those who believe, (and) purely for them on the Day of Judgment. Thus do We explain the Signs in detail for those who know" [42].

7. Mosque decoration is acceptable provided it becomes essential to the structure and serviceability of mosques. In other words, not only should the decoration of mosques not become a liability to mosques, but also not stand out as just a surplus to the requirements of mosques. Rather, mosque decoration must function as "a constitutive element, not an accident, an adjunct of structure, a help in the additional but not necessary art of beautification."[1], [43].

8. Finally, mosque decoration is to appropriately and ingeniously feature enlightening, inspiring and soothing ingredients, such as suitable Qur'anic verses, the Prophet's traditions, wise proverbs, symmetry, geometric and floral patterns, clever use and manipulation of colors and light, etc. This way, an additional role is to be assigned to the mosque institution and its architectural and artistic dimensions, the role of what could be called a silent da'wah Islamiyyah (promoting Islam and inviting people to it). Da'wah Islamiyyah in mosque art and architecture connotes the inviting of non-Muslims to study, appreciate and even embrace Islam, as well as inviting Muslims to understand, value and practice Islam better, but through some novel and hitherto unknown architectural and aesthetic means and ways. The earliest Muslim example of using buildings and building decoration systems as a means for promoting a spiritual mission and cause could be traced back to the creation of the Dome of the Rock in Jerusalem which was initially completed in $72 \mathrm{H} / 691 \mathrm{AC}$ at the order of the Umayyad caliph 'Abd al-Malik b. Marwan [44].

\section{THE ROLE OF THE ISLAMIC SPIRITUALITY IN MOSQUE DECORATION}

Conditional mosque decoration is regarded permissible, mainly, due to the fact that in Islam pursuing beauty and appreciating beautiful objects are intrinsic in man. It is beneficial for one's attainment of joy and happiness in this world and helps one to concentrate on the matters that would guarantee happiness in the Hereafter as well. Prophet Muhammad (pbuh) has thus said that Allah is beautiful and loves beauty [45]. The role of the Islamic spirituality in mosque decoration, and in causing it to become eventually accepted, was thus fundamental. Diverse strategies, means and media have been perfected for the purpose of asserting and enhancing the multi-tiered functions of mosque decoration.

Subtle symmetry and order dominate the subject of mosque decoration whose motif vocabulary is, in turn, dominated by calligraphy and the arabesque, or infinite pattern. The subject matter of the calligraphy content is the themes from the Noble Qur'an and the Prophet's Sunnah. Calligraphy is astonishingly rich in style and modes, and it combines the greatest geometrical strictness with the most melodious [4], [46]. Moreover, besides the art of letters, calligraphy designs have involved a wide variety of other motifs as well. Geometric figures, nongeometric abstract shapes, elements and marks derived from letters and word shapes, and stylized and denaturalized shapes from nature are all commonly found in the calligraphic designs of Islamic art [47], [43], [46].

The most prominent subject matter dominating the motif vocabulary of arabesque in mosque decoration, on the other hand, is abstract shapes (geometric figures) and heavily stylized and denaturalized figures from nature, ranging from flora, fauna and lifeless objects. The reason for this is that the qualities of Allah, the most Beautiful, Whose immeasurable effects permeate and sustain all things, and to Whom all aesthetic expressions endeavored by humankind ought to show the way, are beyond human comprehension and description. The use of revealed and other spiritually loaded letters and words to create a beautiful pattern or design, as well 
as the use of intricate abstract patterns having no beginning and no end, which give an impression of infinity, are therefore the best way to express in art the doctrine of Islamic monotheism [47].

The calligraphic messages engraved on the walls, ceilings, domes and pillar panels of mosques are never selected in a haphazard manner. Rather, they are always carefully selected in order that the purposes of buildings and their decorative schemes are duly served. Hence, in almost all mosques across the Muslim lands decorative calligraphic messages affirm and remind of the nature, supremacy and glory of God the Creator and His infinite attributes and actions. They also affirm and remind people of the character of the life on earth, their position on earth, and what kind of relationship ought to exist between a person and their Lord, parents, family members, other people, and the whole of nature. A good number of the Qur'anic verses, perceived as vital for the comprehension of the above-mentioned subjects, are found to be repetitive in most mosques.

Consequently, upon entering a mosque whose decorative system has been well executed, visitors are bound to find themselves transported into a spiritually pulsating atmosphere unrivalled anywhere outside. In the interior milieu, with a fervent desire and minimum effort, one can feel how great and absolute God is, and how insignificant and vulnerable, on the other hand, they are; how consequential the subduing of this world with all its passing whims for the benefits of the hereafter is, and how inconsequential and detrimental, on the other hand, bartering the latter for the benefit of the former is; and how simple and manifest the true guidance of God is, and how absurd and thorny all manifestations of falsehood and error, on the other hand, are. Once inside a building of this kind, a servant of Allah finds their sixth sense suddenly awaken and stimulated, resulting in the whole being aching for a thought, or word, or an act of service and worship to the Almighty, the source of all beauty and good.

Hence, it goes without saying that the substance of mosque decoration aims at declaring a big 'no' to the corporeality of existence and to its potentially hazardous attractions, and a big 'yes' to that which refreshes and rejuvenates the soul which incessantly yearns for the spirit of divinity the soul feeds on before finally returning to it. However, given that the components of the same corporeal reality have been employed for the production of the built environment, the ultimate appearance of the latter has to be delicately transfigured and denaturalized in order that the refined requirements of Islamic aesthetics are duly met. It is feared that without recourse to both transfiguration and denaturalization in the Islamic built environment, the spiritual purpose of erecting buildings might be harder to attain [4]. Thus, the role of Islamic decoration is a principal and essential one, not a secondary or an auxiliary one. Decoration stands at the heart of the identity of Islamic architecture.
The messages that genuine mosque decoration explicitly and implicitly contains are bent on signaling, reminding and, if necessary, shaking up the spiritual lethargy of the users of mosques which are adorned with Islamic decorative themes. Its aesthetic appeal is not the only constitutive element of a mosque, nor is it an end in itself. Rather, the aesthetic appeal of mosque decoration could be seen as a threshold from where an intuitive observer sets off for a deeper exploration of the inner value of Islamic art and architecture. Also, mosque decoration's instantaneous aesthetic appeal could be seen as an inducement or even a snare, so to speak, in order that the attention of a mosque's users and visitors is somewhat ensured, thus paving the way for communicating the more profound meaning and significance mosque decoration entails.

It is because of this that calligraphic inscriptions in mosques, be they Qur'anic verses, Prophet Muhammad's hadiths or any other wise declarations, are never selected in a haphazard manner. Rather, any examination of the calligraphy systems of mosques suggests that the choice was, in the main, very selective and accurate glorifying God the Creator and humbling man the creation.

As a result of such a powerful religious consciousness and zeal, mass in mosques time and again -- is literally made invisible. This is achieved by covering it with stucco, tile, wood and other materials that transfigure the mass into something radically and totally new and different [47], [48], [46] Buildings simply appear as though enveloped within dissimilar pleasing, dynamic and contemplationprovoking webs of colored decoration. Sometimes when no rich decoration with plentiful motifs and themes is used on a mosque's surfaces, due to the lack of, say, materials, expertise, resources, or even interest, other practical alternatives are then conceived instead, so as to satisfy the same Islamic aesthetic taste. Some of such alternatives are wide-ranging brick patterning, when brick is a major building material; the clever use of marble and stone in bands of contrasting colors, when stone is a major building material[48](Hillenbrand, 1994); laying emphasis on ingenious symmetry in design as well as in organization of inner spaces and architectural motifs, and so on. When touching on the subject of decoration in Islamic architecture, its techniques, language and materials, Ibn Khaldun (1967) naturally concluded, "Thus, the walls come to look like colorful flower beds [49]”.

Since decoration must not interfere with people's concentration in prayers, the decoration carved inside and immediately next to the mihrab (imam's or prayer leader's niche) section, in particular, and on the qiblah wall, in general, normally stands above the eye- level. Certainly, this is not a wide-spread custom by chance [4]. The Muslims are strongly advised to fix their sight in prayers on the place of prostration to ensure full concentration. This decree was issued by the Prophet (pbuh) when mosque decoration had a long way to go and when nobody was giving it serious consideration. 
Thus, in most mosques on the lower section of the qiblah wall, decoration is either completely nonexistent or greatly minimized so that its potentially negative impact during prayers is thwarted. The upper section of the qiblah wall is reserved for rich decoration with a rich Islamic artistic vocabulary.

According to some sound traditions, the Prophet (pbuh) used to incline his head during prayers and fix his sight towards the ground. When he prayed inside the Ka'bah, his sight did not leave the place of his prostration until he came out from it. People must refrain from looking up at the sky in their prayers. Nor can their look wander here and there. Closing one's eyes is also not recommended. The Prophet (pbuh) said: "So when you pray, do not look here and there, for Allah sets His Face towards the face of His slave in his prayer as long as he does not look away." Looking here and there is "a snatching away which the devil steals from God's servant during the prayer." The Prophet (pbuh) also said: "Allah does not cease to turn to a slave in his prayer as long as he is not looking around; when he turns his face away, Allah turns away from him" [50].

It is true that the mihrab area in most mosques receives more attention than most other sections of the mosque. However, it should be observed that the finely contemplative decorative elements, such as intricate geometric patterns and highly stylized and elaborately denaturalized floral elements, rather than the instructive or inadequately denaturalized representative ones in the form of letters or pictures or symbols dominate most aesthetic expressions of mihrabs. While the decorative strategy of the latter can easily upset one's concentration as soon as one makes contact with it because it is specifically informative and sometimes even instructive, the impact of the former, however, is arguably less unsettling because in order to enliven the value and meaning of either abstract geometric or denaturalized floral elements, one needs more than just a casual look. Nonetheless, a casual look here is not to be necessarily seen as a hindrance. This is so because a short casual look at an abstract decorative element may generate no more than a sort of vague but soothing and poignant feeling for the soul whose mission is to concentrate in worshipping acts, but at the moment of making contact with an element of abstraction, it may struggle to do so. In this case, the generated feeling, if controlled and rightly focused, can be rather a helpful experience for the success of a worshipping act. One can wonder then, why there should be anything seriously abhorrent in the whole process when it contains more positives than negatives? Actually, in theory, not much could be categorized as wrong. When it comes to practice, though, people were extremely cautious for the reason that there was much at stake, i.e., carrying out worship obligations in the best possible way and in the purest of all conditions.

Thus, it seems reasonable to theorize that since one needs more than just a nonchalant gaze to experiencing the abstract geometric and denaturalized floral elements, people tolerated such elements in mihrabs more than the instructive or poorly denaturalized representative elements. The people's obvious preference can also be explained on the grounds that geometric abstractions tend to radiate some universal and all-purpose principles and values which can be found underpinning, somehow or other, the core of each and every act of religious worship. It is thus not that hard to make the aura exuded by geometric abstractions, which have been infused with a spiritual substance at the levels of both their conception and execution, harmonious with the spirit and wide-ranging requirements of Islamic worship. If this type of decoration is unable to enhance one's focus in worship, then, should one really want it, it will not lead one easily away from the same either.

In the same vein, the instructive and poorly denaturalized representative elements in the form of letters or pictures or symbols were less favored in mihrabs because the values and experiences that they tend to emanate are revealing and rather explicit. In such a case, the emphasized specific experiences and values of this type of decoration are not always exactly as those featured in an act of worship that is being performed. Thus, this dichotomy between two different spiritual experiences and moods is likely to sporadically get in the way of one's spiritual and mental concentration in that particular act of worship. The extent of the potential damage in one's focus depends on how often and how strongly the said dichotomy presents itself in one's mind.

As a final point, the above discussion only demonstrates that people appear to be torn between the benefits of authentic decoration and the potential hazards of having the same adorning mihrabs and qiblah walls. They attempt to strike a balance between the two neither to miss out on any of the many advantages of decoration nor to compromise any of the prerequisites of both worship ('ibadah) and the mosque institution.

However, whether a decoration system will work or otherwise is determined by nobody else but the people themselves. They can decide whether to avail themselves of the benefits of decoration or to expose themselves to the prospective drawbacks the same entails. They can conceive, implement and then make full use of decoration. They can get what they want so they are fully responsible for the net results. However, it seems nowadays that in many mosques the issue whether the qiblah wall and mihrabs should be decorated is not really a big one nor is the impact decoration exerts on people. As the latent advantages of decorating those two sections of the mosque appear not to be adequately explored and are not of a real concern to many people, likewise neither do the latent disadvantages of the same appear to be a threat to many people's concentration in worship, and, as such, rank high in the hierarchy of their religious interests. This is so because so many worldly items, 
needed or otherwise, have been introduced to the qiblah wall and mihrab areas that the decoration applied on them is simply outdone by the roles and "performances" of those items. As a result, the people, by and large, stay oblivious to the presence of decoration and its significance and role. They neither benefit from it nor does anyone's focus in prayers seem to be made vulnerable by it. This is not a good development, though, because generating and appreciating beauty is an intrinsic thing that has many beneficial aspects. People should always delve into the positives of decoration and avail themselves of their benefits. As some disadvantageous facets of decoration are unwelcome, so is having decoration standing idle and disregarded by most people a fairly inappropriate matter. That is against more than a few religious precepts, such as comprehensive excellence, attentiveness, prudence and wisdom.

On the other hand, seldom do those dominant worldly items, which are placed near the qiblah wall and its mihrab, contain any spiritual substance. As a result, their presence where they are might cause more harm than benefit, in the spiritual sense of the expression. It goes without saying, therefore, that the priorities of people should be properly sorted out, such is the target and a segment of a total Islamization process in Muslim societies. Some of the pure worldly items we are referring here to are clocks of various types and sizes and with various auditory qualities, bookshelves with books, calendars often with pictures of mosques or natural landscapes, posters containing prayer times and also pictures of mosques and landscapes, fans, loud speakers, doors, windows, electronic boards flashing prayer times or other "relevant" information, a table or a chair with some objects on them, pasted notices instructing, for example, that books should be returned to bookshelves after use or that hand phones should be switched off, or that lines (sufuf) should be straightened, etc. To this also we can add the presence of praying mats and carpets which are scarcely plain. Quite often, the pictures of mosques, or some of their sections, are found on them, especially the three holiest mosques in Islam: Ka'bah in Makkah, the Prophet's Mosque in Madinah and the alMasjid al-Aqsa in Jerusalem.

Consequently, there are many contemporary fatwas or religious edicts which strongly recommend removing richly and inappropriately decorated praying mats or carpets from mosques, as well as a range of often instructive spiritual inscriptions positioned next to the qiblah wall and its mihrab [51]. Surely, the above discussed points were one of the reasons why many scholars throughout history were against praying on anything except on bare earth. Some even went so far as to regard praying mats as a repulsive innovation, which however is far from being the case [3].

\section{CONCLUSION}

Prophet Muhammad (pbuh) is reported to have said: "He who builds a mosque for Allah, Allah will build for him likewise in Paradise"[26], [27]. Based on this and many other traditions, plus the Prophet's personal practices, building mosques and thus seeking the pleasure of Allah so that people's collective worship is facilitated, is one of the most desirable and so rewarding activities. Mosques vary in size and function: from simple places meant for a small group of people to perform collectively their daily prayers, to large and impressive masterpieces that function as both the catalysts and centers for the development of community.

Building mosques out of societal needs falls within the category of wajib or obligation. It is an Islamic dictum that if an obligation (wajib) cannot be fulfilled without something, the latter then becomes an obligation (wajib) as well. Undeniably, an obligation is providing Muslim communities with places for collective worship and for other beneficial communal activities. Without them, Muslim communities wouldn't be able to assert themselves and perform their expected roles both locally and internationally; their members wouldn't be complete Muslims.

Prophet Muhammad (pbuh) has said that Allah is beautiful and loves beauty [45]. It is for this that the whole of Allah's creation has been designed and created according to the highest heavenly standard of splendor, beauty and order. Man, the vicegerent on earth, is beautiful too. He has been created "in the best of moulds"[52]. Moreover, creating and appreciating beautiful objects and experiences is a passion instinctive to man. Given that Islam is a natural and rational religion, it opposes neither artistic creativity nor the enjoyment of beauty. On the contrary, it blesses the beautiful and promotes it. It sees absolute beauty only in Allah and in His revealed will or words [47], [53].

This general tenet applies to all the facades of existence, both religious and secular. Hence, moderate and meaningful mosque decoration is directly neither forbidden nor authorized. The matter rests within the category of permissibility (ibahah). It remains so until something comes about and causes it to infringe some of the divinely prescribed ethical norms and standards and renders it either recommended against (makruh) or prohibited (haram). Prohibited outright are representations abhorrent to the Islamic tawhidic worldview such as the idealization of wrongdoing, innovations (bid'ah), individualism and self-realization, as well as excessive and meaningless embellishment elements and styles that promote extravagance, conceit, haughtiness, rivalry, the squandering of people's time, resources and energy.

Moreover, mosque decoration is permissible in principle because pursuing beauty and appreciating beautiful objects are innate in man. Such is conducive to one's realization of tranquility, joy and happiness in this world, thus helping one to concentrate on the matters that would guarantee happiness in the Hereafter as well. As such, Islam, being a natural religion and its path being a middle and 
moderate one, did not proscribe beauty and the beautiful, no matter in which life's sphere they are to be pursued [54].

Finally, despite the austere living of the first Muslims, including the Prophet (pbuh), no one doubted that the subsequent swift cultural and civilizational developments in the Muslim state would herald the imminent advent of disparate crafts. Because they are something additional to just making a living, the number and quality of crafts always depend on the extent of the civilization in the cities, as well as on the sedentary culture and the luxury people enjoy [50]. The same formula governs approving, appreciating, performing and promoting arts too in that they also fall within the realm of crafts. And the same, furthermore, might be asserted as far as the subject of decoration and ornamentation is concerned, for the reason that the relationship between it and the birth and germination of arts is causal, the latter always being the cause of the former. In other words, decorative or applied arts in Islamic architecture bearing a totally new identity could only originate -- and it, in fact, did -- when the Muslims attained a discernible civilizational strength and identity, for Islamic architecture via its status, function and form was epitomizing such strength and identity.

\section{REFERENCES}

[1] Al-Faruqi. Isma'il Raji, Islam and Architecture. Inside: Fine Arts in Islamic Civilization, Edited by: M.A.J. Beg, Kuala Lumpur: The University of Malaya Press. pp. 99-117, 1981.

[2] Al-Hariri. Mahmud b. Husayn, Ahkam al-Masajid fi al-Islam, Riyadh: Dar al-Rifa'i, 1990

[3] Al-Zarkashi. Muhammad, I'lam al-Sajid bi Ahkam al-Masajid, Cairo: Wizarah al-Awqaf, 1996

[4] Burckhardt. Titus, Art of Islam, London: World of Islam Festival Publishing Company Ltd, 1976

[5] Ibn Majah, Sunan Ibn Majah, Tradition No. 733, New Delhi: Kitab Bhavan, 2008

[6] Al-Bukhari, Sahih al-Bukhari, Tradition No. 6588, Dammam: Dar Ibn al-Jawzi, 2011

[7] Abu Dawud, Sunan Abi Dawud, Tradition No. 379. Amman: Dar al-I'lam, 2003

[8] Abu Dawud, Sunan Abi Dawud, Tradition No. 378 Amman: Dar al-I’lam, 2003

[9] Al-Bukhari, Sahih al-Bukhari, Tradition No. 360, 361, Dammam: Dar Ibn al-Jawzi, 2011

[10] Abu Dawud, Sunan Abi Dawud, Tradition No. 1735, Amman: Dar al-I'lam, 2003
[11] Ibn Hanbal. Ahmad, Musnad Ahmad ibn Hanbal, Tradition No. 16039, Amman: Mu'assasah alRisalah, 2008

[12] Abu Dawud, Sunan Abi Dawud, Tradition No. 3263, Amman: Dar al-l'lam, 2003

[13] Muslim, Sahih Muslim, Tradition No. 5246, 5276, Beirut: Dar al-Ma'rifah, 2010

[14] Abu Dawud, Sunan Abi Dawud, Tradition No. 4559 Amman: Dar al-I'lam, 2003

[15] Muslim, Sahih Muslim, Tradition No. 3933, Beirut: Dar al-Ma'rifah, 2010

[16] Ali. Abdullah. Yusuf, The Holy Qur'an, English Translation of the Meanings and the Commentary. Kuala Lumpur: Islamic Book Trust, 2006

[17] Al-Bukhari, Sahih al-Bukhari, Tradition No. 50, Dammam: Dar Ibn al-Jawzi, 2011

[18] Al Qur'an, Surah al-An'am :119

[19] Omer. Spahic, Studies in the Islamic Built Environment. Kuala Lumpur: International Islamic University Malaysia, 2002

[20] Ibn Hanbal. Ahmad, Musnad Ahmad ibn Hanbal, Tradition No. 3418, Amman: Mu'assasah alRisalah, 2008

[21] Al-Jawziyya. Ibn al-Qayyim, Al-Fawa'id, Beirut: Dar al-Kutub al-'Ilmiyyah, 1999

[22] Al-Bukhari, Sahih al-Bukhari, Tradition No. 1255, Dammam: Dar Ibn al-Jawzi, 2011

[23] Yahya. Ahmad, Al-Bahr al-Zakhkhar, http://feqh.al-islam.com, Accessed October 30, 2011

[24] Sabiq. al-Sayyid, Fiqh al-Sunnah (Kitab al-lbadat). Translated into English by Muhammad Sa'id Dabas and Jamal al-Din M. Zarabozo, Washington: American Trust Publications, 1991

[25] (Al-An'am 165). Ali, Abdullah, Yusuf. (2006). The Holy Qur'an, English Translation of the Meanings and the Commentary. Kuala Lumpur: Islamic Book Trust.

[26] Al-Bukhari, Sahih al-Bukhari, Tradition No. 431, Dammam: Dar Ibn al-Jawzi, 2011

[27] Muslim, Sahih Muslim, Tradition No. 828, Beirut: Dar al-Ma'rifah, 2010

[28] Muslim, Sahih Muslim, Tradition No. 429, Beirut: Dar al-Ma'rifah, 2010 
[29] Al-Hariri. Mahmud b. Husayn, Ahkam al-Masajid fi al-Islam. Riyadh: Dar al-Rifa'i, 1990

[30] Ibn Hanbal. Ahmad, Musnad Ahmad ibn Hanbal, Tradition No. 15431, Amman: Mu'assasah alRisalah, 2008

[31] Ibn Majah, Sunan Ibn Majah, Tradition No. 681, New Delhi: Kitab Bhavan, 2008

[32] Al Qur'an, Surah al-Nur:36

[33] Ibn Hanbal. Ahmad, Musnad Ahmad ibn Hanbal, Tradition No. 312, Amman: Mu'assasah alRisalah, 2008

[34] Al-'Asqalani. Ibn Hajar, Fath al-Bari bi Sharh Sahih al-Bukhari, Cairo: Maktabah al-Kulliyyah alAzhariyyah, 1978

[35] Al-Zuhayli, Al-Figh al-Islami wa Adillatuh, Damascus: Dar al-Fikr, 1989

[36] Abd al-Hamid, Ibrahim. Hal Tajuz Zakhrafah alMasajid?, http://www.onislam.net/arabic/ask-thescholar/8240/8394/8319/50364-2004-08-01\%2017304.html, Accessed December 26, 2013

[37] Al-Albani. Muhammad. Naasir-ud-Deen, Kitab Ahkam al-Masajid. Kuwait: Gharas li al-Nashr wa al-Tawzi', 2004

[38] Ibn 'Asakir. Ali, Tarikh Madinah Dimashq. Beirut: Dar al-Fikr, 1995

[39] al Qur'an, Surah al-A'raf : 31

[40] Abu Dawud, Sunan Abi Dawud, Tradition No. 3541, Amman: Dar al-I'lam, 2003

[41] Al- Nasa'i, Sunan al-Nasa'i, Tradition No. 5128, Urdun: Bayt al-Afkar al-Dawliyah, 2004

[42] al Qur'an, Surah al-A'raf:32

[43] Lois. Lamya. al-Faruqi, Islam and Art, Islamabad: National Hijra Council, 1985
[44] Goitein. S.D, Studies in Islamic History and Institutions. Leiden: E. J. Brill, 1968

[45] Muslim, Sahih Muslim, Tradition No. 164, Beirut: Dar al-Ma'rifah, 2010

[46] Nasr. Seyyed. Hossein, Islamic Spirituality: Manifestations. New York: Crossroad Publishing Company, 2012

[47] Al-Faruqi. Isma'il. Raji, Al-Tawhid: its Implications for Thought and Life, Herndon: International Institute of Islamic Thought, 1995

[48] Hillenbrand. Robert, Islamic Architecture, Edinburgh: Edinburgh University Press, 1994

[49] Ibn Khaldun, The Muqaddimah, Translated from the Arabic by Franz Rosenthal, abridged and edited by N. J. Dawood, London: Routledge and Kegan Paul, 1967

[50] Al-Albani. Muhammad Naasir-ud-Deen, The Prophet's Prayer: To Look at the Place of Prostration, and Humility, http://muttaqun.com/prayer/07.html, Accessed October 8, 2011.

[51] Al-Bulayhid. Khalid b. Sa'ud, Tanbih A'immah alMasajid Hawl Ta'liq al-Lawa'ih fi al- Qiblah, http://saaid.net/Doat/binbulihed/129.htm, Accessed December 26, 2013.

[52] al Qur'an, Surah al-Tin : 4

[53] Isa. Ahmad. Muhammad, Muslims and Taswir. Inside: Fine Arts in Islamic Civilization, Edited by: M.A.J. Beg. Kuala Lumpur: The University of Malaya Press, pp. 41-68, 1981

[54] Nasr. Seyyed. Hossein, Islamic Spirituality: Manifestations, New York: Crossroad Publishing Company, 2012 